\title{
DETERMINANTS OF HOUSEHOLD RECYCLING
}

\author{
Slađana Pavlinović Mršić \\ Anita Stojan $^{* *}$
}

Received: 6. 4. 2020

Accepted: 31. 5. 2020

DOI https://doi.org/10.30924/mjcmi.25.1.16

\author{
Professional paper \\ UDC" 351:628.4 (497.583Split) \\ 334.724: 502.174.1 (497.583Split)
}

\begin{abstract}
A case of managing a public utility in post-transitional context is elaborated in this paper. The aim is to identify main determinants of household recycling, in order to make recommendations for design of appropriate recycling policy in Split (Croatia). Based on the overview of relevant literature, individual motivation towards waste selection is explored and preliminary survey results are presented. Implications for local policy-making and management of local public utilities are discussed.
\end{abstract}

Key words: waste recycling management, Split (Croatia), policy-making, local public utilities

\section{INTRODUCTION}

Croatia is a post-transitional country, which became an EU member state in 2013 which obligated the country to introduce advanced waste selection management practices. However, cities in Croatia face significant problems with respect to introduction of household waste selection system. Renko Luttenberg (2020) points out that only several Croatian local governmental units exceeded 50\% recycling target for municipal waste, laid down in Sustainable Waste Management Act (OG, 94/13, 73/17,
14/19, 98/19). The EU legislation imposes penalties on countries, which do not meet required targets, and thus local governmental units have to pay those penalties if they do not comply with the Act (Republic of Croatia, 2017). Thus, local governments must create appropriate policy mix, which will enable meeting the targets. In order to understand and propose appropriate household waste selection policy mix, individual motivation and behavioural mechanisms need to be elaborated. Determinants of waste selection are discussed in the next section and an overview of extrinsic and intrinsic motives for recycling is presented. Results of a preliminary empirical study, conducted in the city Split, are presented in the third section. Results are discussed and policy recommendations as well as managerial implications for public utilities are suggested in the fourth section.

\section{DETERMINANTS OF WASTE RECYCLING}

Inquiries on how to motivate citizens to adopt and improve recycling practices induced research in various disciplines.

\footnotetext{
* Slađana Pavlinović Mršić, PhD, Assistant professor, University of Split, Faculty of Economics, Business and Tourism, Cvite Fiskovića 5, 21000 Split, Croatia, E-mail: spavlino@efst.hr

** Anita Stojan, Student, University of Split, Faculty of Economics, Business and Tourism, Cvite Fiskovića 5, 21 000 Split, Croatia, E-mail: anitastojan1@gmail.com
} 


\section{Journal of Contemporary Management Issues}

Factors which determine recycling behaviour are discussed in this section. Beside socio-demographic factors, various psychological factors may play an important role. Economic mechanisms, such as fines and subsidies, may impact recycling, but Barr (2007) points out that psychological factors affect individual buying decisions, as well as product use and waste disposal, and thus might play crucial role in sustainable waste management.

\subsection{Demographic factors}

Secondi et al (2015) use the data from Flash Eurobarometer no. 388 to explore food waste behaviour among EU-27 citizens. They apply order logit model and introduce country-specific variables, as to conclude that female respondents, as well as those over 65 , tend to produce less food waste. This is in line with Barile et al. (2015:10), who find that female respondents are more likely to provide a higher contribution to recycling than male ones. However, when variable on environmental moral is introduced, the finding related to gender becomes less robust. Barile et al. (2015:10) also suggest that willingness to contribute has an inverse U-shaped relation with age.

According to Secondi et al. (2015), inhabitants of rural areas tend to produce less food waste, while higher education and income are associated with higher quantities of food waste. This is confirmed by Cerciello et al. (2018), who associate areas with higher income level in Italy with the tendency to waste more food. On the other hand, Vasileva and Ivanova (2014, in: Stoeva and Alriksson, 2017:334) suggest that Bulgarians, who live in urban areas, have above-average income and are welleducated, show positive attitudes towards waste separation. Kalambura et al. (2016) confirm the importance of education in waste management.

\subsection{Psychological factors}

The economics literature emphasises difference between intrinsic and extrinsic motives for environmentally friendly behaviour (Cecere et al. 2014; Barile et al., 2015.). Furthermore, D’Amato et al. (2016) differentiate two types of behaviour. While recycling is mainly normative (extrinsic) behaviour, waste reduction behaviour reflects personal environmental values (intrinsic motives). Cecere et al. (2014) use the Fash Eurobarometer 316 data and analyse the impact of intrinsic and extrinsic motives on environmentally friendly behaviour. Respondents, who are not inclined towards Pigovian tax, declare to produce less food waste, while respondents who are considering environmental impact of products are more likely to waste a higher percentage of food. On the other hand, Secondi et al (2015) use the Flash Eurobarometer 388 data and find that food waste reduction is positively associated with the support of the Pigovian tax. Finally, D'Amato et al. (2016) empirically examine if reduction and recycling are substitutes or complements and conclude that these two activities complement each other. Therefore, one needs to be aware that extrinsic motives (such as environmental taxation schemes) may be complements or substitutes to intrinsic motives (Cecere et al., 2014:166).

Barile et al. (2015) conducted an empirical analysis to compare efficiency of behavioural measures, ('nudges', i.e. measures intended to change individual behaviour, but preserve the individual choices and 'shoves', i.e. different government interventions). Authors also construct a green moral index (Barile et al., 2015:10), in order to measure individual intrinsic value for 
pro-environmental behaviour. Their analysis indicates that individuals, with a high 'green moral' better react to 'nudges', while others better react to 'shoves'. This might suggest that the choice of instruments for waste recycling should be particularly designed to target individuals, depending on their intrinsic motivation towards environmental protection.

Finally, dynamics of pro-environmental contributions need to be taken into consideration. Truelove et al. (2014) analysed the correlation between various pro-environmental actions of individuals. They find that a pro-environmental action can negatively affect their future pro-environmental behaviour. Reasons can be economic (related to substitution and income effects), or psychological (as individual may not feel a moral duty to engage in future pro-environmental activities, since they might feel that the existing contribution has been sufficient, which is referred to as to the moral balance sheet).

\subsection{Social factors}

Secondi et al. (2015) find that the individual perception of social behaviour and norms ('living in an area with little or no litter') is associated with a smaller amount of food waste. Cerciello et al. (2018) further analyse how pro-environmental behavioural patterns, with respect to food waste, spread spatially, which may be related to the social contacts.

In order to understand the individual decision-making, related to waste recycling, the authors review different factors which may influence individual recycling behaviour (see Table 1 for intrinsic and Table 2 for extrinsic motives). Intrinsic motives are derived from individual attitudes, values, etc., while extrinsic motivation is based on external determinants. Motives such as pure altruism can be considered intrinsic, since their rewards are purely internal and derived from the individual's knowledge of his/her pro-social behaviour. Motives involving material rewards, such as tax breaks, may be considered extrinsic, since instrumental behaviour is connected to obtaining an external reward (Cecere et al., 2014). The following tables illustrate the internal vs. external motives, studies in which they were examined, as well as the questionnaire items used.

Table 1. Intrinsic motivation

\begin{tabular}{|l|l|l|l|}
\hline Variables & Description & Source & Items \\
\hline $\begin{array}{l}\text { Intrinsic } \\
\text { motivations }\end{array}$ & $\begin{array}{l}\text { A motivation that comes from } \\
\text { 'within the person's attitude', in } \\
\text { the absence of an external reward } \\
\text { (Cecere et al.,2014) }\end{array}$ & (Cecere et al.,2014) & \\
\hline 'Warm-glow' & $\begin{array}{l}\text { In the absence of external } \\
\text { monetary incentives, people } \\
\text { work for an internal moral } \\
\text { reward. Warm-glow is personal } \\
\text { satisfaction arising from an } \\
\text { activity independent of its impact } \\
\text { (Abbot et al. 2013). }\end{array}$ & $\begin{array}{l}\text { Abbott et al., (2013.- } \\
\text { str.2), } \\
\text { Barile et al.,(2015), } \\
\text { Cecere et al.(2013), } \\
\text { Cecere et al.,(2014), } \\
\text { Damato et al., (2016), } \\
\text { Kirakozian (2016) }\end{array}$ & $\begin{array}{l}\text { Asking respondents } \\
\text { to assess their level of } \\
\text { contribution, in terms of } \\
\text { effort spent on recycling } \\
\text { activities given the } \\
\text { assumption that they had to } \\
\text { bear in mind the time and } \\
\text { trouble costs of recycling } \\
\text { activities. }\end{array}$ \\
\hline
\end{tabular}


Journal of Contemporary Management Issues

\begin{tabular}{|c|c|c|c|}
\hline Variables & Description & Source & Items \\
\hline Joy of giving & $\begin{array}{l}\text { People's own utility function is } \\
\text { directly and positively influenced } \\
\text { by the well-being of others. }\end{array}$ & $\begin{array}{l}\text { Cecere et al.(2013), } \\
\text { Cecere et al.(2014), } \\
\text { Kirakozian (2016) }\end{array}$ & \\
\hline $\begin{array}{l}\text { Pro- } \\
\text { environmental } \\
\text { behaviour }\end{array}$ & $\begin{array}{l}\text { Those who are willing to reduce } \\
\text { and reuse waste are also more } \\
\text { likely to believe that, although } \\
\text { humans have the right to live in } \\
\text { a clean environment, individuals } \\
\text { have the responsibility to act } \\
\text { properly (Barr et al., 2001). } \\
\text { It is often observed that } \\
\text { individuals with higher } \\
\text { education levels tend to be more } \\
\text { environmentally friendly (Meyer, } \\
\text { 2015). }\end{array}$ & $\begin{array}{l}\text { Barr et al., (2001), Barile, } \\
\text { (2012), Meyer, (2015) }\end{array}$ & $\begin{array}{l}\text { In the questionnaire survey } \\
\text { 'environmental morale' was } \\
\text { inferred from the responses } \\
\text { to a set of questions in } \\
\text { which individuals were } \\
\text { asked to indicate how } \\
\text { often they take specific } \\
\text { 'green' actions (such as } \\
\text { save water, recycle, turn } \\
\text { off lights, walk, cycle or } \\
\text { take public transport) for } \\
\text { environmental reasons } \\
\text { (Barr et al., 2001). }\end{array}$ \\
\hline
\end{tabular}

Source: Authors

Table 2. Extrinsic motivation

\begin{tabular}{|c|c|c|c|}
\hline Variables & Description & Source & Items \\
\hline $\begin{array}{l}\text { Extrinsic } \\
\text { motivation }\end{array}$ & $\begin{array}{l}\text { Behaviour is influenced both } \\
\text { by the desire to achieve a } \\
\text { positive self-image and to } \\
\text { gain the respect and approval } \\
\text { of others. }\end{array}$ & $\begin{array}{l}\text { Cecere et al.(2014), } \\
\text { Kirakozian, (2016) }\end{array}$ & \\
\hline Financial taxes & $\begin{array}{l}\text { The individual responds to } \\
\text { "economic" (or "external") } \\
\text { incentives - taxes, subsidies, } \\
\text { fines, mandatory policies }\end{array}$ & $\begin{array}{l}\text { Barile et al., (2015), } \\
\text { Kirakozian, (2016) }\end{array}$ & $\begin{array}{l}\text { Whether and to what extent } \\
\text { 'representative individuals' } \\
\text { are motivated by } \\
\text { 'environmental morality' } \\
\text { and how often they perform } \\
\text { the 'green actions' (such } \\
\text { as saving water, recycling, } \\
\text { switching off lights, } \\
\text { walking and using public } \\
\text { transport). }\end{array}$ \\
\hline Social norms & $\begin{array}{l}\text { Social norms can be regarded } \\
\text { as valuable beliefs about } \\
\text { how to treat something that } \\
\text { is socially acceptable. Thus, } \\
\text { penalties for non-compliance } \\
\text { come from the society } \\
\text { (Barile, 2012). }\end{array}$ & $\begin{array}{l}\text { Abbott et al.,(2013), } \\
\text { Barile, (2012) }\end{array}$ & \\
\hline
\end{tabular}




\begin{tabular}{|c|c|c|c|}
\hline Variables & Description & Source & Items \\
\hline $\begin{array}{l}\text { Reciprocal } \\
\text { altruism }\end{array}$ & $\begin{array}{l}\text { As a tool to support and } \\
\text { enforce social norms and } \\
\text { regulations, reciprocal } \\
\text { altruism can be interpreted as } \\
\text { a norm enforcement device } \\
\text { (Barile, 2012). }\end{array}$ & Barile, (2012) & \\
\hline BIN policy/prizes & $\begin{array}{l}\text { A local authority } \\
\text { acknowledges the intrinsic } \\
\text { value of waste recycling by } \\
\text { providing recycling materials } \\
\text { and services without charge } \\
\text { (Barile et al., 2015). }\end{array}$ & $\begin{array}{l}\text { Barile, (2012), Barile et } \\
\text { al., (2015), Crociata et } \\
\text { al., (2015) }\end{array}$ & \multirow{2}{*}{$\begin{array}{l}\text { Respondents were asked } \\
\text { to respond to each of these } \\
\text { incentives, given the extent } \\
\text { to which they said they } \\
\text { were willing to recycle. } \\
\text { Possible answers were: "I } \\
\text { would use the same level of } \\
\text { effort", "I would increase } \\
\text { my contribution", and "I } \\
\text { would reduce the effort". }\end{array}$} \\
\hline $\begin{array}{l}\text { FINE policy/ } \\
\text { penalties }\end{array}$ & $\begin{array}{l}\text { The local authority threatens } \\
\text { to monitor individual } \\
\text { compliance and to fine } \\
\text { individuals, if they do not } \\
\text { recycle household waste } \\
\text { (Barile et al., 2015). }\end{array}$ & Barile et al., (2015), & \\
\hline $\begin{array}{l}\text { Pay-as-you-throw } \\
\text { (PAYT) }\end{array}$ & $\begin{array}{l}\text { PAYT is a charge for } \\
\text { residents for quality of waste } \\
\text { thrown away (D'Amato et al., } \\
\text { 2016). }\end{array}$ & $\begin{array}{l}\text { D'Amato et al., (2016), } \\
\text { Kirakozian,(2016), }\end{array}$ & \\
\hline
\end{tabular}

Source: Authors

\section{WASTE RECYCLING IN THE CITY OF SPLIT}

According to the Law on sustainable waste management, each local governmental unit in Croatia is obligated to recycle at least $50 \%$ of glass, paper, plastic and metal waste until 2020. Surprisingly, although the waste selection system exists, the amount of waste recycled in Split is below 4\% (City of Split, 2020). Such a result requires careful consideration of various factors, which determine the individual motivation to recycle. This has been determined by using a survey on waste recycling, which has included different socio-demographic groups. Also, elements of pro-environmental moral were considered.

The survey was conducted between 20 June and 10 July 2018, using an online platform, as well as face-to-face interview, with respondents at several locations of the city of Split. The collected primary data provides information on the waste management behaviour of 215 individuals. The research instrument (questionnaire) is based on the previous literature review. Details are presented by the following table. 
Journal of Contemporary Management Issues

Table 3. Questionnaire items

\begin{tabular}{|c|c|c|}
\hline Items & Variables & Measurement scale \\
\hline $\begin{array}{l}\text { You are willing to pay more for products that are } \\
\text { more environmentally friendly. }\end{array}$ & Willingness to pay & \multirow{2}{*}{$\begin{array}{l}\text { 1- Completely disagree } \\
\text { 2-Disagree } \\
\text { 3- Undecided } \\
\text { 4-Agree } \\
\text { 5-Completely agree }\end{array}$} \\
\hline You are too worried about environmental issue & Environmental care & \\
\hline $\begin{array}{l}\text { Do you dispose of waste in public places, which } \\
\text { are not designated for waste disposal? }\end{array}$ & Effect on environment & $\begin{array}{l}\text { 1-Never } \\
\text { 2-Sometimes } \\
\text { 3-Often } \\
\text { 4-Always }\end{array}$ \\
\hline $\begin{array}{l}\text { Do you believe that the damage caused to nature is } \\
\text { the result of the inadequate waste disposal? }\end{array}$ & $\begin{array}{l}\text { Environmental } \\
\text { consequences }\end{array}$ & \multirow{5}{*}{$\begin{array}{l}0 \text {-No } \\
1 \text {-Yes }\end{array}$} \\
\hline $\begin{array}{l}\text { Are you willing to put more effort to sort waste and } \\
\text { recycle, as to influence the other citizens? }\end{array}$ & $\begin{array}{l}\text { Influence on others to } \\
\text { sort waste }\end{array}$ & \\
\hline Do you recycle your waste? & Waste recycling & \\
\hline $\begin{array}{l}\text { Would you put more effort into recycling, if you } \\
\text { were rewarded? }\end{array}$ & BIN policy & \\
\hline $\begin{array}{l}\text { Would you change your behaviour if there were a } \\
\text { fine for avoiding recycling? }\end{array}$ & FINE policy & \\
\hline $\begin{array}{l}\text { Would the recycling practice of your neighbours } \\
\text { influence your behaviour? }\end{array}$ & Influence of neighbours & \multirow{2}{*}{$\begin{array}{l}\text { 1- Completely false } \\
\text { 2-False } \\
\text { 3- Neither true nor false } \\
\text { 4-True }\end{array}$} \\
\hline $\begin{array}{l}\text { Would the advice of your friends and family } \\
\text { influence your behaviour? }\end{array}$ & $\begin{array}{l}\text { Influence of friends and } \\
\text { family }\end{array}$ & \\
\hline What is your gender? & Gender & $\begin{array}{l}\text { Female }-0 \\
\text { Male-1 }\end{array}$ \\
\hline What is your age? & Age & $\begin{array}{l}\text { 1-Under } 25 \text { years } \\
\text { 2-Between } 25 \text { and } 50 \\
\text { years } \\
\text { 3-Between } 50 \text { and } 75 \\
\text { years } \\
\text { 4-Over } 75\end{array}$ \\
\hline What is your employment status? & Occupation & $\begin{array}{l}\text { 1-Self-employed } \\
\text { 2-Employee } \\
\text { 3-Unemployed } \\
\text { 4-Student } \\
\text { 5- Retired }\end{array}$ \\
\hline Which degree have you obtained? & Education & $\begin{array}{l}\text { 1-Elementary school } \\
\text { 2-High school } \\
\text { 3- Bachelor degree } \\
\text { 4-Master degree }\end{array}$ \\
\hline $\begin{array}{l}\text { On a scale of } 1 \text { to } 10 \text {, indicate your financial } \\
\text { satisfaction, where } 10 \text { represents extreme } \\
\text { satisfaction and } 1 \text { extreme dissatisfaction. }\end{array}$ & Financial satisfaction & \\
\hline
\end{tabular}

Source: Authors 
A little bit more than a half of the respondents $(50,47 \%)$ confirmed that they recycle waste. Analysis of waste recycling behaviour across demographic groups is presented in Table 4. There is no obvious effect of gender, while waste recycling across age groups fits well the Barille's (2015) U-shape willingness to contribute to environment. Finally, almost $60 \%$ of respondents with the highest level of education engage in waste recycling, while the figures are slightly lower for lower education levels, which is comparable to findings of Vasileva and Ivanova (2014, in: Stoeva and Alriksson, 2017:334), as well as to those of Kalambura et a.1 (2016).

Table 4. Individuals who engage in recycling waste

\begin{tabular}{|l|l|l|}
\hline \multicolumn{3}{|l}{$\%$ of individuals who recycle } \\
\hline \multirow{4}{*}{ Gender } & Female & $50 \%$ \\
\cline { 2 - 3 } & Male & $51 \%$ \\
\hline \multirow{4}{*}{ Education } & $<25$ & $52 \%$ \\
\hline & $25-50$ & $44 \%$ \\
\cline { 2 - 3 } & $50-75$ & $59 \%$ \\
\hline & High school & $52 \%$ \\
\cline { 2 - 3 } & Bachelor degree & $44 \%$ \\
\cline { 2 - 3 } & Master degree & $59 \%$ \\
\hline
\end{tabular}

Source: Authors

Additionally, four indicators are, based on the factor analysis, initially used to construct the 'green moral index' (Barille, 2015). Those include: willingness to pay for environmentally friendly products, attention to the environment, a belief that environmental damage is caused by inadequate waste collection, and willingness to recycle waste as well as influence others to do the same. Each factor is positively, but weakly, correlated with the waste recycling behaviour (correlation coefficients vary between 0.18 and 0.23). However, standard economic instruments, such as rewards and penalties, are almost uncorrelated with the waste recycling behaviour (with correlation coefficients values of -0.07 and 0.03 ).

\section{DISCUSSION}

On one hand, official statistics on communal waste recycling in Split are discouraging. On the other hand, half of the participants of a randomised survey stated that they do recycle. The difference in results may be based on a fact that this survey does not discriminate the individual involvement in recycling, so that respondents who made a very small waste recycling effort also replied affirmatively. This issue should be taken into account in future survey design.

Analysis of demographic variables leads to conclusions which are in line with the relevant literature. High education positively affects recycling, while age correlation with recycling is U-shaped meaning that middle age respondents are less likely to select waste. Surprisingly, female and male respondents equally recycle their waste, although it was expected that females would recycle more. Therefore, a more comprehensive quantitative analysis is necessary in order to check robustness of the presented results. Finally, analysis of environmental moral indicates a weak correlation with the waste recycling practice, while correlation between economic instruments and waste selection is negligible.

The current state of the waste selection management in Split shows that existing technical measures of the public utilities are not sufficient. The previous discussion suggests that they need to be complemented by targeted marketing, which requires careful analysis of individual motivation, 


\section{Journal of Contemporary Management Issues}

decision-making and behaviour. However, those managerial implications, developed from the viewpoints of the local government and public utility organizations, open up new questions for analysis and research: 1) What is the most efficient strategy to increase recycling? 2) Is it possible to target individuals? 3) Which measures can be applied to target individuals? 4) Is it more efficient to target individuals who do not recycle, or to support a more intensive recycling of those, who already engage in the recycling behaviour?

The EU recycling targets require adequate response of local public utilities, which perform the waste management. With this aim, those companies can apply monetary measures, such as penalties or rewards, which requires precise monitoring of the waste recycling practices across households. However, it has been indicated that monetary rewards and penalties can adversely affect individual recycling practices in some cases. Thus, the local public utilities should also consider the effects of reciprocal altruism and social norms, since the waste selection represents a contribution to the public good. This can be exploited by informing the customers about waste recycling practices in the local community. Targeted promotion of good practices can motivate public utilities' customers to put an additional effort into recycling.

If individuals who do not recycle are targeted, then the results of this study imply that utility companies should particularly incentivise middle aged customers with bachelor degrees. On the other hand, if the focus is on those who already recycle, then waste recycling should be promoted among younger citizens with higher education. An interesting preliminary insight of this study is that pro-environmental morality is not strongly correlated with the waste recycling behaviour.
A similar recommendation is related to referring to social norms in appropriately designed marketing campaigns, targeting the citizens to change their recycling behaviour. Furthermore, public utilities might, also, consider implementing instruments based on the intrinsic motivation, in an effort to educate customerswhiletaking into consideration their psychological preferences.

Finally, preliminary analysis of correlation between various tools and waste recycling behaviour indicates that their "fine tuning' is required. For instance, individuals who are already inclined to waste recycling may react adversely to monetary incentives. These tools can, also, complement each other, so that a customer, with environmental preferences, might reach the 'tipping point' and start recycling, as a response to a welltargeted marketing campaign.

\section{CONCLUSION}

Determinants of household waste recycling are analysed in this paper. Empirical research is conducted on a sample of residents of the city of Split, with socio-demographic and psychological factors considered. Despite typical economic instruments, such as rewards and penalties, being usually applied in recycling selection policy design, intrinsic motives for recycling should be taken into consideration as well. In line with the previous findings, waste recycling varies with age and education. Opposite to expectations, gender differences were not found among respondents. Further comprehensive statistical analysis is required, in order to confirm or reject these findings. Results suggest that the targeted waste recycling policy design may be considered, in order to encourage citizens to recycle. However, further research is required in 
order to define which citizens are optimal to being targeted. Finally, the existence of an attitude-behaviour gap occurs between a very low share of recycled waste in Split and the amount of respondents, who claim to recycle, which calls for a further analysis.

\section{REFERENCES}

1. Abbott, A., Nandeibam, S. i O'Shea L. (2013): Recycling: Social norms and warm-glow revisited. Ecological Economics, 90:10-18.

2. Barile, L., Cullis, J., Jones, P. (2015): Will one size fit all? Incentives designed to nurture prosocial behavior, Journal of Behavioral and Experimental Economics, 57:9-16

3. Barr, S., Gilg, A. W., \& Ford, N. J. (2001). A conceptual framework for understanding and analysing attitudes towards household-waste management. Environment and Planning, 33(11), 2025-2048.

4. Barile, L. (2012): The Impact of Governmental Signals on Environmental Morale. A 'Behavioural' Approach, Bath Economics Research Papers, 3/12

5. Barr, S. (2007): Factors Influencing Environmental Attitudes and Behaviors: A U.K. Case Study of Household Waste Management, Environment and Behavior, 39 (4):435-473

6. Cecere, G., Mancinelli, S., Mazzanti, M. (2014): Waste prevention and social preferences: the role of intrinsic and extrinsic motivations, Ecological Economics, 107:163-176

7. Croatian Government portal (2020): Complete waste management system. Downloaded at: https://vlada.gov.hr/ cjeloviti-sustav-gospodarenja-otpadom/11408, (April 23, 2020)
8. Cerciello, M., Agovino, M., Garofalo, A. (2018): Estimating urban food waste at the local level: are good practices in food consumption persistent?, Economia Politica, 36: 863-886

9. City of Split - City Council (2020): A report on company "Čistoća" Split for 2019, based on Law on Sustainable waste management, March 9, downloaded at: https://sjednice.split.hr/pdfv iewer $/ 2223$ ?backUrl $=\% 2 \mathrm{~F} \% 231 \% 2 \mathrm{~F} 57$ \&signature $=2 \mathrm{e} 9394 \mathrm{ec} 7 \mathrm{f} 262 \mathrm{bd} 02535 \mathrm{~d} 9$ 38c601d4aa508c4831bdfbb4e88104bb 73c9428253 (April 23, 2020)

10. Crociata, A., Agovino, M., Sacco, P. L. (2015): Recycling waste: Does culture matter?, Journal of Behavioral and Experimental Economics, 55:40-47.

11. Crociata, A., Agovino, M., Sacco, P. L. (2016): Neighborhood effects and pro-environmental bahvior: The case of Italian separate waste collection, Journal of Cleaner Production, 135:80-89

12. D'Amato, A., Mancinelli, S, Zoli, M. (2016): Complementarity vs substitutability in waste management behaviours, Ecological Economics, 123:84-94

13. Kalambura, S., Racz, A., Jovičić, $\mathrm{Nj.}$, Toth, M. (2016): Perception of problems opportunities and navigation of waste selection, Social Ecology, 25(3)

14. Kirakozian, A. (2016): The determinants of household recycling: social influence, public policies and environmental preferences, Applied Economics, 48(16):1481-1503

15. Kirakozian, A. (2016): One without the other? Behavioural and incentive policies for household waste management, Journal of Economic Surveys, 30(3):526-551

16. Meyer, A. (2015): Does education increase pro-environmental behavior? 


\section{Journal of Contemporary Management Issues}

Evidence from Europe. Ecological Economics 116: 108-121.

17. Republic of Croatia (2017): Decision on the adoption of the Waste Management Plan of the Republic of Croatia for the period 2017. - 2022., Official Gazette, 3, downloaded at: https://narodne-novine.nn.hr/clanci/sluzbeni/full/2017_01_3_120.html (April 24, 2020)

18. Republic of Croatia (2013): Sustainable Waste Management Act, Official Gazette, 94/13, 73/17, 14/19, $98 / 19$
19. Secondi, L., Principato, L., Laureti, T. (2015): Household food waste behaviour in EU-27 countries: A multilevel analysis, Food Policy, 56:25-40

20. Stoeva, K., Alriksson, S. (2017): Influence of recycling programmes on waste separation behaviour, Waste Management, 68:732-741

21. Truelove, H. B., Carrico, A. R., Weber, E. U., Raimi, K. T., Vandenbergh, M. P. (2014): Positive and negative spillover of pro-environmental behaviour: An integrative review and theoretical framework, Global Environmental Change, 29:127-138

\section{ODREDNICE RECIKLIRANJA OTPADA U KUĆANSTVIMA}

Sažetak. U ovom se radu izlaže studija slučaja upravljanja javnim komunalnim poduzećem u post-tranzicijskom kontekstu. Cilj rada je identificirati ključne odrednice recikliranja u domaćinstvima, kako bi se izradile preporuke za donošenje odgovarajuće politike recikliranja u gradu Splitu (u Hrvatskoj). Na temelju pregleda relevantne literature, analizira se motivacija za odvajanje otpada te se prezentiraju rezultati preliminarne ankete. Diskutiraju se implikacije za lokalne javne politike i menadžment lokalnih komunalnih poduzeća.

Ključne riječi: upravljanje recikliranjem otpada, Split (Hrvatska), donošenje javnih politika, lokalna komunalna poduzeća 